\begin{tabular}{|c|c|}
\hline Title & A ssessment of forest carbon stocks for REDD+ implementation in the muyong forest system of Ifugao, Philippines \\
\hline Author(s) & A vtar, Ram; Tsusaka, Kenichi; Herath, Srikantha \\
\hline Citation & $\begin{array}{l}\text { Environmental Monitoring and A ssessment, 192(9), } 571 \\
\text { https://doi.org/10.1007/s10661-020-08531-8 }\end{array}$ \\
\hline Issue Date & $2020-09$ \\
\hline Doc URL & http:/hdl.handle.net/2115/82597 \\
\hline Rights & $\begin{array}{l}\text { This is a post-peer-review, pre copy edit version of an article published in Environmental Monitoring and A ssessment. } \\
\text { The final authenticated version is available online at: https://doi.org/10.1007/s10661-020-08531-8 }\end{array}$ \\
\hline Type & article (author version) \\
\hline File Information & Environ.Monit.A ssess. v192(9)p.571.pdf \\
\hline
\end{tabular}

Instructions for use 


\section{Assessment of Forest Carbon Stocks for REDD+ Implementation in the Muyong Forest 2 System of Ifugao, Philippines}

3 Ram Avtar $^{1}$, Kenichi Tsusaka ${ }^{2}$, Srikantha Herath ${ }^{3}$

$4 \quad{ }^{1}$ Faculty of Environmental Earth Science, Hokkaido University, Japan

5 'United Nations University, Institute for the Advanced Studies of Sustainability (UNU-IAS),

6 Tokyo, Japan

$7 \quad{ }^{3}$ Ministry of Megapolis and Western Development, Battaramulla, Sri Lanka

8 Email: ram.envjnu@gmail.com; +81-11-706-2261

\section{Abstract}

Forests hold significant potential for carbon sequestration and climate change mitigation.

11 Forest biomass estimation is vital for sustainable forest management, providing critical input

12 data for implementing the United Nations Reducing Emissions from Deforestation and forest

13 Degradation-plus (REDD+) mechanism. This study investigates the total carbon pools14 aboveground biomass (AGB), belowground biomass (BGB), forest floor biomass, and soil 15 carbon-using field-based information in the muyong forest management system, which is 16 native to Ifugao in the Philippines. This study reveals that a difference may be observed between 17 the total carbon stock of the private woodlots (muyong) and that of the communal forest (bilid).

18 The results indicate that the bilid forest has trees with small diameter at breast height (DBH) and 19 high tree density in contrast to the muyong, which has trees with high DBH and low tree density. 20 The average carbon stock per unit area is higher in muyong (150.8 tC/ha) than in bilid (126.1 $21 \mathrm{tC} / \mathrm{ha}$ ). These findings are valuable in determining whether Ifugao's muyong forest system 22 should be included under the REDD+ framework. Human mediation and management helps 23 forests to sequester a greater amount of carbon than they would without human intervention. 24 Implementation of REDD+ should promote Ifugao's ecosystem and biodiversity conservation 25 and agroforestry practices in addition to protecting traditional agricultural practices and 26 livelihoods in relation to rice terraces.

27 Keywords: Forest carbon stocks, REDD+, muyong, climate change mitigation

\section{1. Introduction}


Tropical forests are important carbon reservoirs, storing large quantities of biomass over long periods compared to agriculture and other systems (Ravindranath and Ostwald 2008; Avtar, et al., 2013a). They also fulfill an important role in the global carbon cycle because they act as reservoirs during succession and sources when deforested or degraded by natural or human disturbances (Marin-Spiotta and Sharma, 2013). Continued deforestation and forest degradation pose the threat of releasing large amounts of carbon, which may exacerbate the effects of climate change. The Philippines is one of the world's seventeen countries recognized as megadiverse and is particularly vulnerable to climate change (World Bank, 2010). The total area of forest cover in the Philippines is 8.4 million hectares with 1,160 million tons of aboveground biomass (AGB) in forests and other woodlands (FAO-FRA, 2015). The promotion of restoration initiatives has the potential to increase the country’s carbon sink.

Deep in the heart of the Philippine Cordilleras mountain range lies the Ifugao province, which is famous for its rice terraces (UNESCO, 2019). The Ifugao agricultural system is an “agro-cultural complex system,” characterized by the interlocking of nature with agricultural practices, social systems, and historical, political, and cultural changes (O’Connor, 1995). The muyong system plays a major role in the survival of the Ifugao rice terraces, providing water and preventing soil erosion (Avtar et al., 2019; Soriano et al., 2019). In the local dialect of the Tuwali tribe, "muyong” translates literally to "forest," although the precise definition may vary depending on the locality. Local people specifically use this term to denote privately-owned and managed woodlots located above rice terraces (payoh). Muyong forests differ from other systems with respect to their management and protection (Herath et al., 2015). The Ifugao land classification system designates land categories according to the location, function, and type of agronomic activity that takes place (Butic and Ngidlo, 2003). The muyong system is Ifugao's native forest management system and is vital to the rice terracing system due to its watershed function (Durst et al., 2001). Globally, it has been acclaimed as a comprehensive ecosystem that provides a host of various ecosystem services.

During the last decade, various efforts have been made to accurately quantify forest carbon stock with the aim of understanding global and regional carbon budgets (Lindsell et al., 2013; Ma et al., 2018). Maps of the spatial distribution of biomass can assist in decreasing uncertainty in relation to the global carbon cycle (Duncanson, 2019). The quantification of 
global forest biomass relies on AGB estimation. Therefore, most recent studies have focused on the estimation of AGB using ground-based and remote sensing-based methods to improve accuracy. AGB can be estimated from ground-based forest inventory parameters using allometric equations (Brown, 1997; Chave et al., 2014). Geospatial data can also be used to improve AGB estimation using various satellite sensor data. Accuracy in biomass estimation is vital for the implementation of climate change mitigation mechanisms such as Reducing Emissions from Deforestation and forest Degradation-plus (REDD+) as well as for forest management in Asian countries (Andoh and Lee, 2018; Borah et al., 2018).

The Ifugao rice terrace system was first recorded as a World Heritage site in 1995 by the United Nations Educational, Scientific and Cultural Organization (UNESCO) (Department of Environment and Natural Resources, 2008). However, the maintenance and conservation of World Heritage sites require financing (Timothy and Nyaupane, 2009). Toorn (2013) found that funding availability is the main issue in the conservation of these cultural landscapes. This study focuses on the assessment of forest biomass stock in the Ifugao system, which will be useful in creating funding opportunities under the existing REDD+ mechanism. Earlier studies have shown that population growth has led to increased demand for firewood and timber products, thereby contributing to deforestation and also affecting ecosystem services (Ravindranath and Ostwald 2008; Avtar et al., 2019). This study explores how REDD+ initiatives can mitigate climate change and value forests to help the traditional cultures of Ifugao communities and livelihoods (UN-REDD 2016). In the Philippines, the Department of Environment and Natural Resources (DENR) is pushing for the nationwide implementation of REDD+ initiatives to reduce the impact of climate change. Lasco et al. (2013) reviewed REDD+ projects in the Philippines and discussed the critical factors for their successful implementation. This study aims to assess the total forest carbon stock of the muyong and bilid forests in Ifugao and its role in climate change mitigation strategies under the REDD+ framework. The REDD+ intervention can also support the area's indigenous people in adopting inventive mechanisms aimed at managing the transformation of the Ifugao economy.

\section{Study Area}

The Nagacadan barangay is one of the fourteen barangays of the Kiangan municipality of the Ifugao province of the Philippines. It is located about 320km from Metro Manila. The total 
population of Nagacadan was 831 as per the 2015 census data. Agriculture and tourism are the main sources of income in the study area. Ifugao is a landlocked mountain province in the

91 epicenter of the Philippine Cordilleras region. The topography of the area is marked by rugged

92 terrain with mountainous forests. The Kiangan is situated in an upland area with an elevation ranges from 500 to 1,300 meters above the mean sea level. The highest point in Ifugao is Mt.

94 Pulag, a popular hiking destination. The Ifugao rice terraces, with an estimated area of 10,323 ha,

95 are listed in the UNESCO World Heritage site as part of the agricultural system used by the 96 Ifugao (Calderon et al., 2009). Figure 1 shows the Ifugao rice terrace system with mountainous 97 areas covered with the muyong and bilid forests. This shows how forest management and rice terraces are complementary to each other.

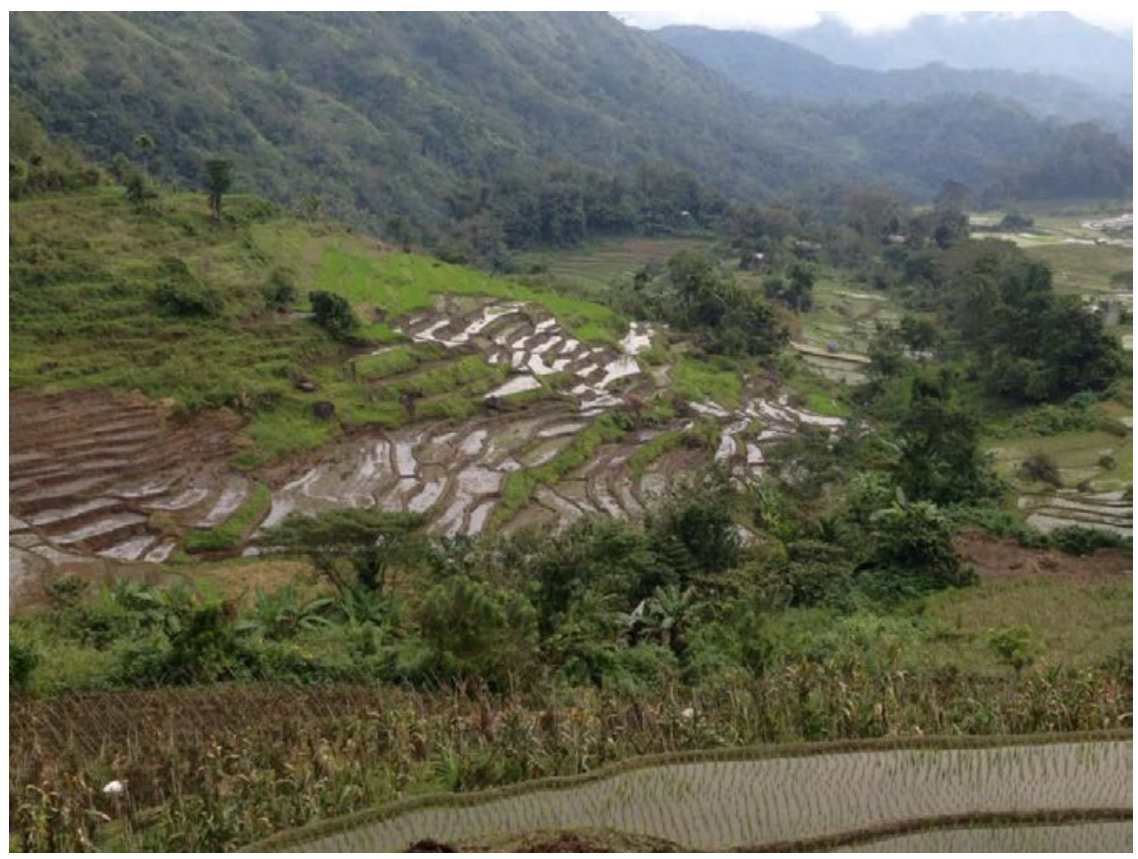

Figure 1. Ifugao rice terraces with mountains covered with muyong and bilid forests

The forests in the region are classified as the amalgamation of moss, pine, and elevation (DEM) data shows the change in the topography in the study area. 


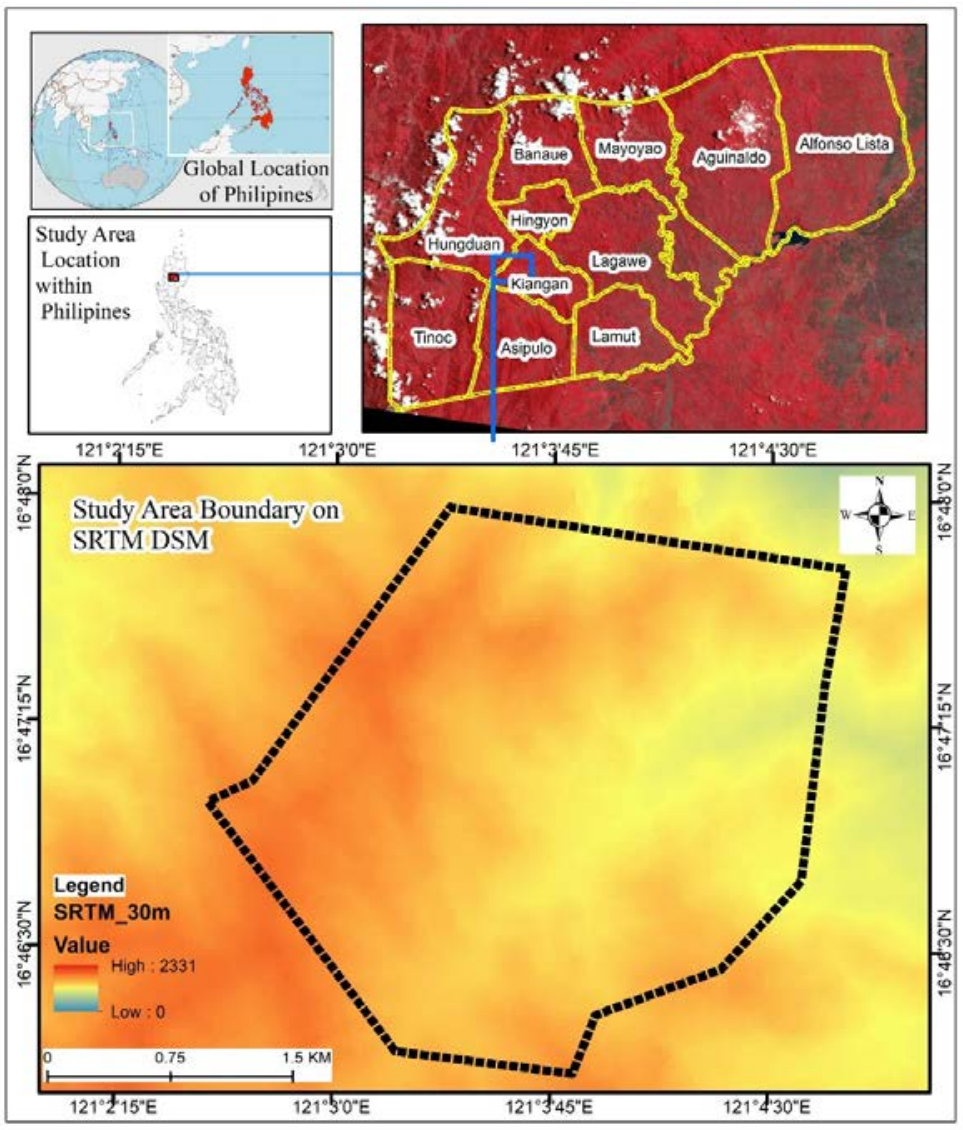

Figure 2. Representation of the study area

107 There are five land use classes in the study area namely: (1) muyong, (2) rice terrace (payoh), (3) 108 bilid, (4) habal, and (5) fallow/open agricultural land. Table 1 shows the land use types in the 109 study site and their description.

Table 1. Various land-use types in the study area

\begin{tabular}{|l|l|l|}
\hline $\begin{array}{l}\text { Land-use } \\
\text { type }\end{array}$ & Ownership & Description \\
\hline Muyong & Private & Forest woodlot \\
\hline Payoh & Private & Rice terrace \\
\hline Bilid & Communal & Forest area around the mountain \\
\hline Habal & Private & $\begin{array}{l}\text { Swidden farms designated for food production located on a } \\
\text { steep incline }\end{array}$ \\
\hline Fallow & Private & Drained rice terraces \\
\hline
\end{tabular}




\subsection{Forest Woodlots (Muyong)}

112

The muyong is a privately managed woodlot with diverse plant species, constituting an important part of the agricultural and social system. Within the context of the local culture, the muyong system is a highly functional and efficient mosaic of forest resources and is the product of thousands of years of experimental learning. The local people have observed a link between forest management and food security. Therefore, the protection of muyong is a vital component for the survival of rice terraces (Dugan et al., 2003). As muyong are located at higher elevations relative to the rice terraces, they are considered to regulate the supply of water, which is essential for rice production. Furthermore, the vegetation helps to reduce surface water runoff and erosion, thus also preventing the sediment accumulation in the underlying paddy fields (Matsushima and Tojo, 2010).

\subsection{Mountain Forest (Bilid)}

The bilid is defined as the forested area around the mountain ridge, which operates under a regime of communal management. Not all of the area on the mountain ridge consists of bilid, as the mountain top is also inhabited by large swaths of tall cane grass and occasional swidden farms (Jang and Salcedo, 2013). The bilid is free for anyone to harvest. Therefore, many farmers take advantage of this when they feel that they have harvested too much from their muyong. The bilid can appear physically similar to a muyong, but it has different management and tenure system.

\subsection{Swidden Fields (Habal)}

Also known as the kaingin in Nagacadan, the habal refers to an area that is explicitly designated for food production. It is one of the most important lands uses in the area and is created through slash-and-burn agriculture. Habal is often established on slopes that are too steep for rice terrace cultivation. As they do not require much maintenance, they are generally located far from the homestead. The habal is a necessary component of the muyong system because local communities rely on it to supplement their diet and it also offers insurance against years with low rice yields (Conklin, 1980). 


\section{Methodology}

This study's methodology was designed to assess forest carbon stocks with the aim of

141 implementing the REDD+ mechanism in Nagacadan, Ifugao. It consists of field- and remote 142 sensing-based biomass estimation. To understand the benefits of the REDD+ mechanism and 143 achieve the objective of this study, forest biomass in the Ifugao system was estimated. Fieldwork 144 was conducted to collect biomass data from February 8-14 2015. We adopted methodologies 145 from Ravindranath and Ostwald (2008) for ground-based biomass calculation using forest inventory data. Avtar et al.'s (2013b) methodologies were used for Phased Array L-band type Synthetic Aperture Radar (PALSAR)-based forest biomass estimation. Figure 3 shows the outline of the methodology for biomass estimation using field-based observation for direct measurement and satellite-based observation for indirect measurement.

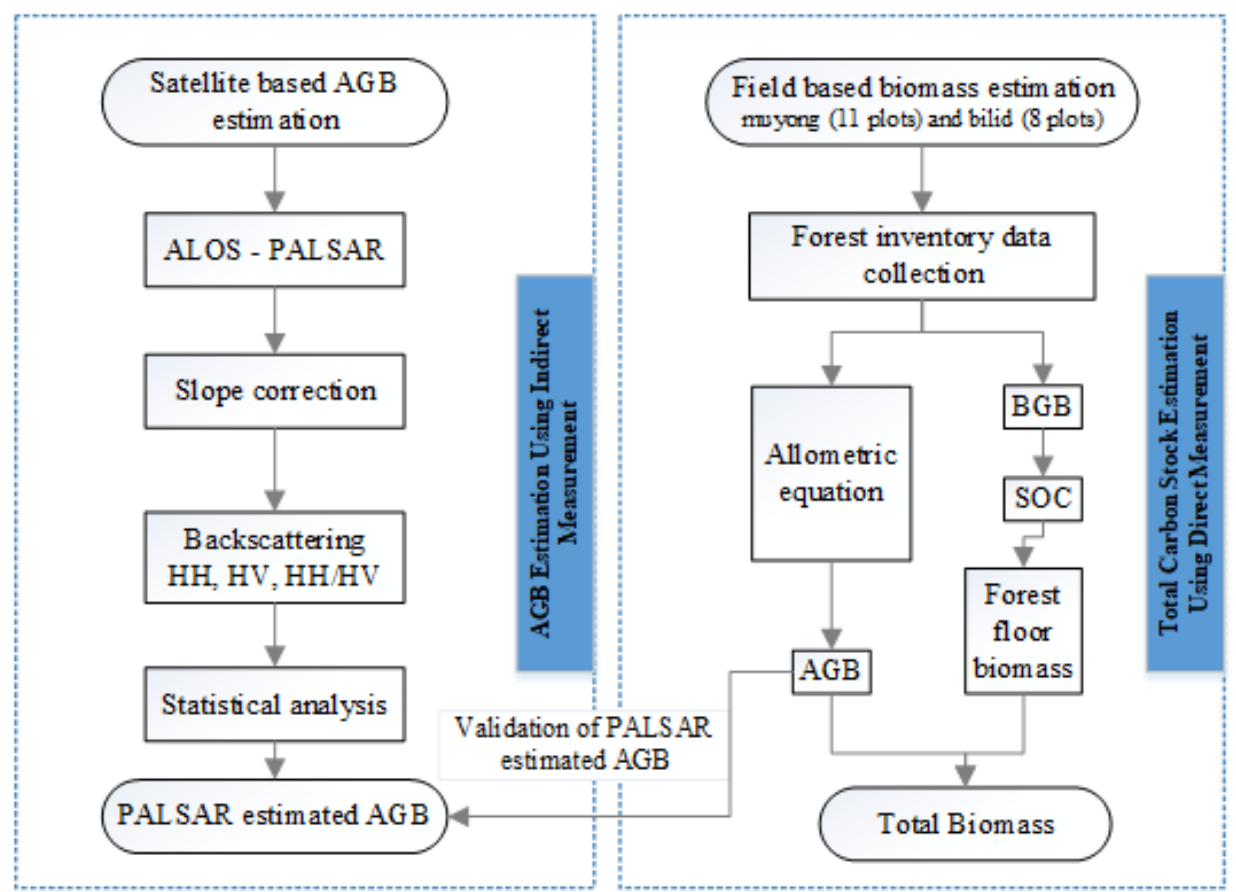

Figure 3. Flow chart of forest biomass estimation using satellite-based and ground-based measurement

Measurement and analysis of different carbon pools were performed to estimate total 154 carbon stock in the forest. In most forest biomass studies, forest biomass and soil organic carbon 155 (SOC) are the two major carbon pools. Forest biomass pools can be further divided into living 156 AGB and belowground biomass (BGB), which includes litter, roots, litterfall, detritus, dead 
organic material, and woody debris (Houghton, 2003). AGB is the major and most evident carbon pool in the terrestrial ecosystem (Ravindranath and Ostwald, 2008). BGB includes live roots that support the carbon cycle by transferring and storing carbon in the soil (Eggleston et al., 2006). Biomass from litter, litterfall, detritus, dead organic material, and woody debris constitutes a small fraction of forest carbon stocks (Ravindranath and Ostwald, 2008). Soil organic matter is also a major contributor to forest carbon stocks and releases $\mathrm{CO}_{2}$ as a consequence of deforestation (Lal, 2005). Table 2 shows the various methods available for measuring different biomass pools and their suitability for carbon measurement. In this study, the plot-based method was used to estimate AGB.

Non-destructive biomass measurement methods are popular in protected areas because AGB estimation can be achieved without destruction of trees. Data collected from sample plots can be used to estimate the mean carbon stock per unit area of each land-use type, which can then be extrapolated using remote sensing techniques (Avtar, Suzuki, et al., 2013b). This method of AGB estimation was considered the most suitable for the study area. However, the presence of steeply sloping mountainous terrain can cause errors and limit the use of synthetic aperture radar (SAR) data. Furthermore, the region's tropical climate is associated with high amounts of cloud cover, which limits the availability of cloud-free multispectral remote sensing data (Minh et al., 2019). Therefore, the use of field-based measurements (in-situ) implementing non-destructive sampling techniques can minimize the uncertainties in AGB estimation.

Table 2. Methods to measure carbon pools (Ravindranath and Ostwald, 2008)

\begin{tabular}{|l|l|l|}
\hline Pools & Methods & Suitability for carbon measurement \\
\hline AGB & Plot method & $\begin{array}{l}\text { Commonly used and familiar method } \\
\text { Cost-effective and suitable }\end{array}$ \\
\cline { 2 - 3 } & Harvest method & $\begin{array}{l}\text { Not appropriate all the time } \\
\text { Time-consuming, labor-intensive and expensive }\end{array}$ \\
\cline { 2 - 3 } & $\begin{array}{l}\text { Plot-less or transect } \\
\text { method }\end{array}$ & $\begin{array}{l}\text { This method is good but it is not suitable in dense } \\
\text { forest as well as for periodical monitoring }\end{array}$ \\
\cline { 2 - 3 } & Modelling & $\begin{array}{l}\text { Need basic input data for building the models } \\
\text { It is suitable for projections }\end{array}$ \\
\cline { 2 - 3 } & &
\end{tabular}




\begin{tabular}{|c|c|c|}
\hline & & Requires basic input parameters \\
\hline & Satellite/remote sensing & $\begin{array}{l}\text { These methods are suitable for regional and national } \\
\text { level monitoring but expensive for small projects. }\end{array}$ \\
\hline & $\begin{array}{l}\text { Carbon flux } \\
\text { measurements }\end{array}$ & $\begin{array}{l}\text { This is an expensive method and requires skilled } \\
\text { people. }\end{array}$ \\
\hline BGB & $\begin{array}{l}\text { Root extraction and } \\
\text { weight measurement }\end{array}$ & Time-consuming, labor-intensive and expensive \\
\hline & $\begin{array}{l}\text { Root to shoot ratio } \\
\text { method }\end{array}$ & This method is commonly used based on AGB data \\
\hline & Biomass equations & Need data e.g. DBH, tree height, girth etc. \\
\hline Dead & Litter & This method needs huge efforts \\
\hline $\begin{array}{l}\text { Organic } \\
\text { matter }\end{array}$ & Stock measurement & This method is commonly adopted and feasible \\
\hline $\begin{array}{l}\text { Soil } \\
\text { carbon }\end{array}$ & $\begin{array}{l}\text { Diffuse reflectance } \\
\text { spectroscopy method }\end{array}$ & $\begin{array}{l}\text { This method is expensive and requires skilled human } \\
\text { resources }\end{array}$ \\
\hline & Modelling & $\begin{array}{l}\text { Need basic input data from other methods and suitable } \\
\text { for projection }\end{array}$ \\
\hline & Laboratory estimation & $\begin{array}{l}\text { This is the most suitable method and commonly } \\
\text { adopted }\end{array}$ \\
\hline
\end{tabular}

\subsection{Carbon Stock Estimation using Direct Measurement}

Field-based biomass estimation methods were used to collect forest inventory parameters with the assistance of local people in the study area. The random sampling method was used to 181 collect forest inventory parameters to measure forest carbon stock. Figure 4 shows the 182 distribution of sampling plots in the Nagacadan area. In this study, temporary sampling plots 183 were used in light of the limited budget. Moreover, we did not intend to conduct long-term monitoring of the biomass pattern. 


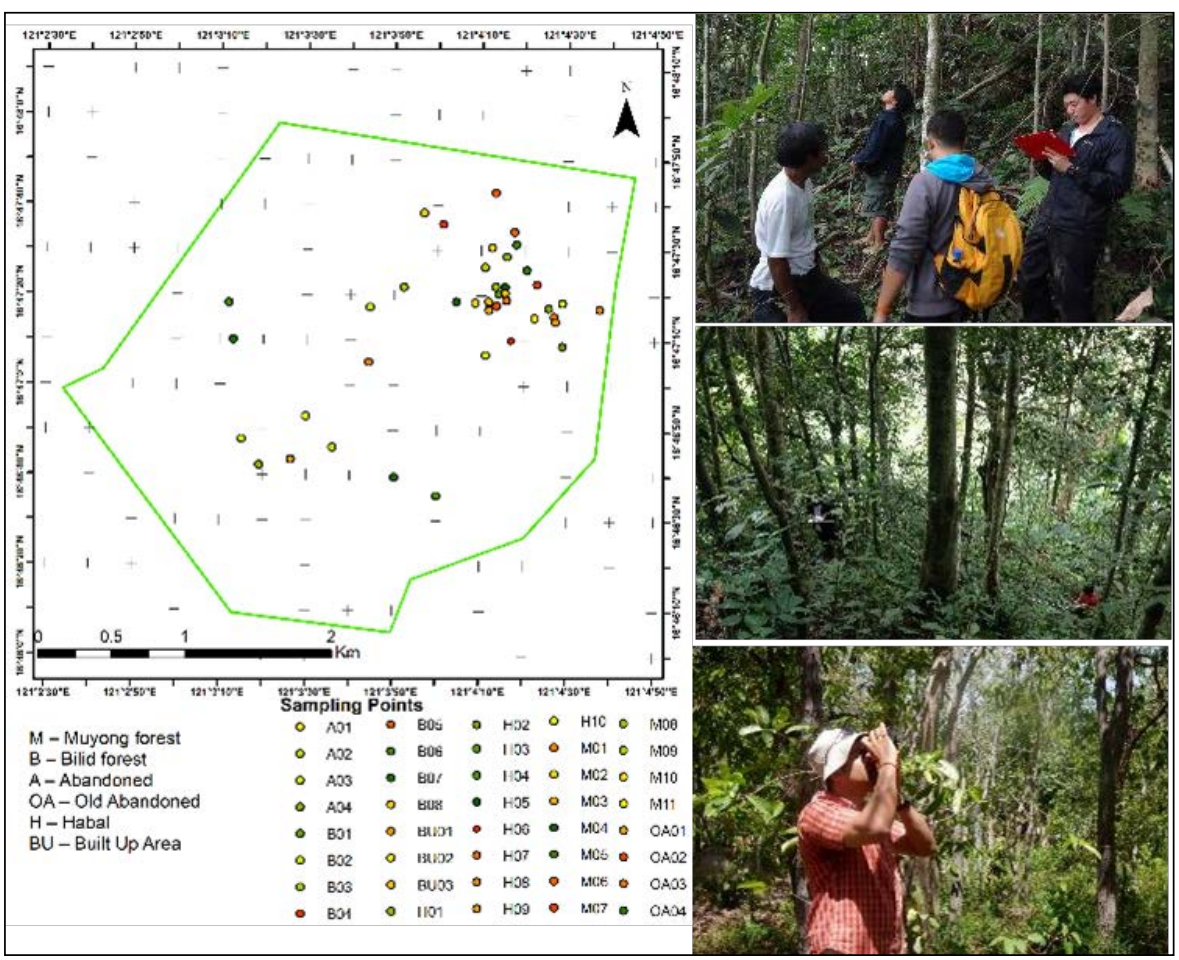

Figure 4. Field data collection and location of sampling plots

Square plots of $10 \times 10 \mathrm{~m}$ were laid out with measuring tape for AGB estimation. The corners of the plots were located with the help of the Global Positioning System (GPS). The shape and size of the sampling plots constitutes a trade-off between time, accuracy, and cost of measurement. Wondo (2013) suggested that square plots tend to include more heterogeneity and favor more representation than circular plots in the same study area (Wondo, 2013). As suggested by Pearson et al. (2005), based on the consideration of medium-size diameter at breast height $(\mathrm{DBH})$ at the study site, we adopted $10 \times 10$-m plots to minimize the heterogeneity. This was also due to the steep slope conditions in the mountainous forest. Moreover, the plots were the same size as the pixels of the Advanced Visible and Near-Infrared Radiometer type-2 205 (AVNIR-2) data.

Data were collected from four carbon pools: AGB, BGB, forest floor biomass, and soil carbon. To estimate forest carbon stock, forest inventory parameters, including tree height, DBH, tree species, tree density, and forest types were collected. Tree height refers to the total height of trees instead of the height of the merchantable stem, which is used in some allometric equations. $\mathrm{DBH}$ of each tree was measured at $130 \mathrm{~cm}$ height from the ground by using $\mathrm{DBH}$ tapes and markers. All the trees with $\mathrm{DBH} \geq 5 \mathrm{~cm}$ were measured with a $\mathrm{DBH}$ tape. To measure the $\mathrm{DBH}$ 
212 in the steep slope, the measurement was conducted on the uphill side of the tree (Ravindranath 213 and Ostwald, 2008).

214 The following allometric equation was used for the AGB calculation (Brown, 1997). It was 215 developed specifically for forest biomass estimation in moist tropical forests and covered most of 216 the species of tropical forests.

$$
\mathrm{AGB}=\exp \left(-2.289+2.649 \times \ln (\mathrm{dbh})-0.021 \times \ln \left(\mathrm{dbh}^{2}\right)\right.
$$

Where, $\ln =$ natural $\log$, exp = “e to the power of”

219 To estimate BGB (root biomass) from the AGB, an allometric equation was used as follows 220 (Ravindranath and Ostwald, 2008):

$$
\mathrm{BGB}=\exp [-1.0587+0.8836 * \ln (\mathrm{AGB})]
$$

$$
\text { Where, } \ln =\text { natural } \log \text {, exp = "e to the power of" }
$$

223 The biomass value obtained from the above equations is converted to carbon stock using a carbon conversion factor of 0.47 (McGroddy et al., 2004).

Soil carbon $=\left[\right.$ soil bulk density $\left(\mathrm{gm}^{-3}\right) \times$ soil depth $(\mathrm{cm}) \times$ soil organic carbon $\left.(\%)\right] \times 100(4)$

The total number of square plots for the collection of forest inventory data for muyong and bilid were 11 and 8, respectively. In contrast to the forest carbon stock and forest floor areas, 
the total number of samples for soil carbon was five (three in muyong, two in bilid). Total carbon stock is the summation of carbon stock from AGB, BGB, forest floor, and soil carbon.

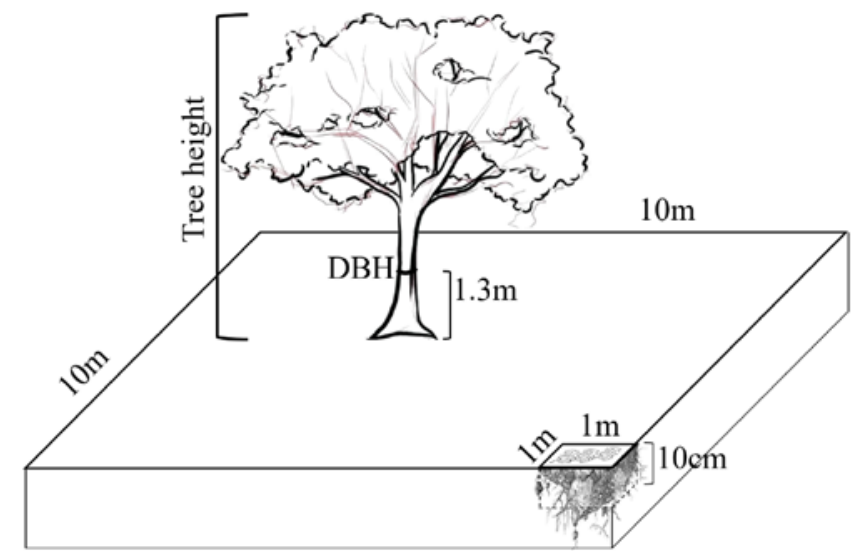

Figure 5. The design of plot samples and carbon measurement in the field

\subsection{Carbon Stock Estimation using Indirect Measurement}

Conventional allometric-based biomass estimation is one of the most accurate methods used in carbon stock estimation. However, it is expensive, time-consuming, and labor-intensive (Avtar et al., 2012; Avtar et al., 2013c; Avtar et al., 2016). Moreover, it is only applicable in small areas for which forest inventory data are available. Remote sensing can overcome the above-mentioned limitations.

Several studies have modeled forest biomass using various satellite sensors (Anaya et al., 2009; Baccini et al., 2004; Drake et al., 2003; Vashum and Jayakumar, 2012). Avtar et al. (2013b) reported that SAR data are more effective than optical data in measuring AGB in tropical regions due to the limitation of clouds. Other studies have shown that light detection and ranging (LiDAR)-based biomass estimation offers greater accuracy than other remote sensingbased observation methods (Nelson et al., 1988; Vashum and Jayakumar, 2012). However, the use of LiDAR data in developing countries is particularly limited owing to acquisition and processing costs. Therefore, PALSAR data were used to estimate AGB in this study. SAR data with cross-polarization (horizontal and vertical: HV) can detect tree volume and are useful in estimating forest biomass (Avtar et al. 2013b). SAR-based backscattering information is useful for estimating forest biomass and has been used extensively by other researchers (Englhart et al., 2011). Furthermore, due to its penetrative capacity, SAR has the advantage of being insensitive 
261 to weather conditions, such as clouds and rain, which is useful in tropical regions. SAR

262 backscatter information is affected by the topography with steep slopes due to layover and 263 foreshortening effects of SAR data (Avtar et al., 2013b).

264

265

266

267

268

269

270

271

272

273

274

275

276

277

278

279

280

281

282

283

284

285

286

287

288

289

The satellite data were acquired from the Advanced Land Observation Satellite (ALOS) mission of the Japan Aerospace Exploration Agency (JAXA) in 2010. AVNIR-2 and PALSAR were used to estimate biomass in the study area. AVNIR-2 is a multispectral image with four bands consisting of blue, green, red, and near-infrared (NIR) bands with a 10-m pixel size. Similarly, PALSAR images have a spatial resolution of approximately $16 \mathrm{~m}$ with dual polarization (Tadono et al., 2009). Land use/land cover (LULC) classification of AVNIR-2 data was performed to distinguish various LULC classes in the study area, including bilid, muyong, rice terraces, built-up areas, grassy mountain terrain, open mountain, and water bodies. The maximum likelihood classification algorithm was used to classify AVNIR-2 data (Lillesand and Kiefer, 1999). Forest cover information can be a useful parameter for calculating total carbon stocks in the study area. Samreth et al. (2012) used remote sensing and a ground-based forest inventory approach to estimate carbon stocks in Cambodian forests. The use of forest area and average carbon stock in a particular forest can provide total carbon stock information. We explored similar methodological approaches to calculate average carbon stock in muyong and bilid forests using the following equation.

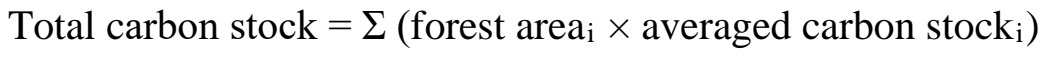

Where, ${ }_{\mathrm{i}}=$ forest types (muyong or bilid)

We also used backscattering information from dual-polarization PALSAR data to estimate AGB using the methodology described in Avtar et al. (2013b). Field-calculated AGB was used to validate the PALSAR-estimated biomass.

\section{Results and Discussion}

This study aimed to assess the forest carbon stocks in the Ifugao system using direct and indirect measurement methods to obtain information from four carbon pools: (1) AGB, (2) BGB, (3) forest floor layer, and (4) SOC. We also attempted to generate a land-use map of the area using AVNIR-2 data and biomass estimation using equation 5. PALSAR-based methods were also used to estimate forest biomass. 


\subsection{Carbon Stock Estimation using Direct Measurement}

291

292

293

294

295

296

297

298

299

300

301

302

303

304

305

306

307

308

309

\subsubsection{Forest Carbon Stock (AGB + BGB)}

To quantify forest carbon stocks, we collected forest inventory parameters (tree height, $\mathrm{DBH}$, species, tree density, and forest types) in muyong and bilid forests. This study evaluated total forest biomass in the Ifugao forest management system. Appendices A1 and A2 show the forest inventory parameters and calculation of forest biomass stocks in the muyong and bilid forests, respectively. Statistical analysis was conducted to compare the various forest inventory parameters. Figure 6 shows the linear regression between tree density and average DBH of the sampling plots. A moderate relationship was observed between tree density and average DBH in muyong with a correlation value of $0.56\left(\mathrm{R}^{2}=0.31\right)$, while a strong relationship was observed in bilid with a correlation value of $0.7\left(\mathrm{R}^{2}=0.49\right)$. As tree density increases, the trees' $\mathrm{DBH}$ values tend to be smaller. The relationship between average $\mathrm{DBH}$ and tree density demonstrates that in dense forests, tree growth rate can be restricted due to the limited space and greater competition among trees for growth determinants such as nutrients, space, and access to sunlight. Similarly, Takahashi et al. (2018) also noticed a large DBH and a low tree density for evergreen conifers in the Shizumo forest reserve. Comparison of average DBH between the muyong and bilid revealed that the muyong features trees with a high average $\mathrm{DBH}$ and low tree density in contrast to the bilid forest. Furthermore, the findings show that tree density per hectare is higher in the bilid, which supports the theory that lack of maintenance allows the natural regrowth of plants in the bilid.

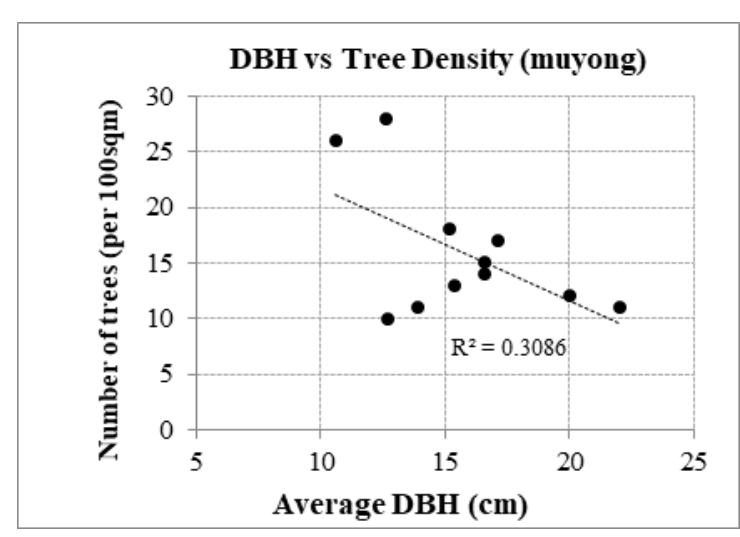

(a)

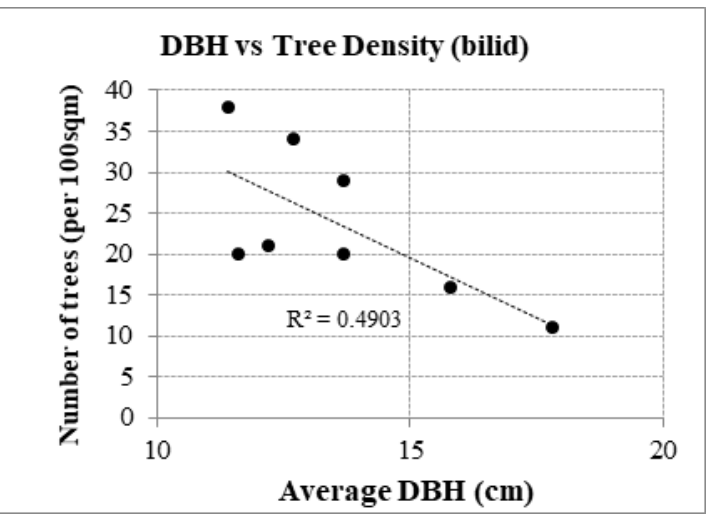

(b) 
Figure 6. Linear regression between DBH and tree density in (a) muyong and (b) bilid

forests

Figure 7 shows a histogram of the $\mathrm{DBH}$ frequency distribution with respect to tree

313

314

315

316

317

318

319

320

321

322

323

324

325

326

327

328

329

330 density. The histogram shows the normal distribution of $\mathrm{DBH}$ in the muyong and bilid. The average and standard deviation of DBH were $15.79 \mathrm{~cm}$ and $11.63 \mathrm{~cm}$ in muyong, while the values were $13.14 \mathrm{~cm}$ and $6.29 \mathrm{~cm}$ in bilid. The muyong showed a greater difference in $\mathrm{DBH}$ than bilid. Despite the uneven number of sample plots, the data support the view that the muyong management system enables the growth of larger trees. This is evidenced by the measurement of the largest tree in the bilid at $36 \mathrm{~cm}$ DBH while 10 trees larger than $36 \mathrm{~cm}$ and one larger than 70 $\mathrm{cm}$ (accounting for 0.6\%) were observed in the muyong. The histogram illustrates the muyong's association with the growth of larger trees owing to the maintenance and protection activities implemented by private forest holders.

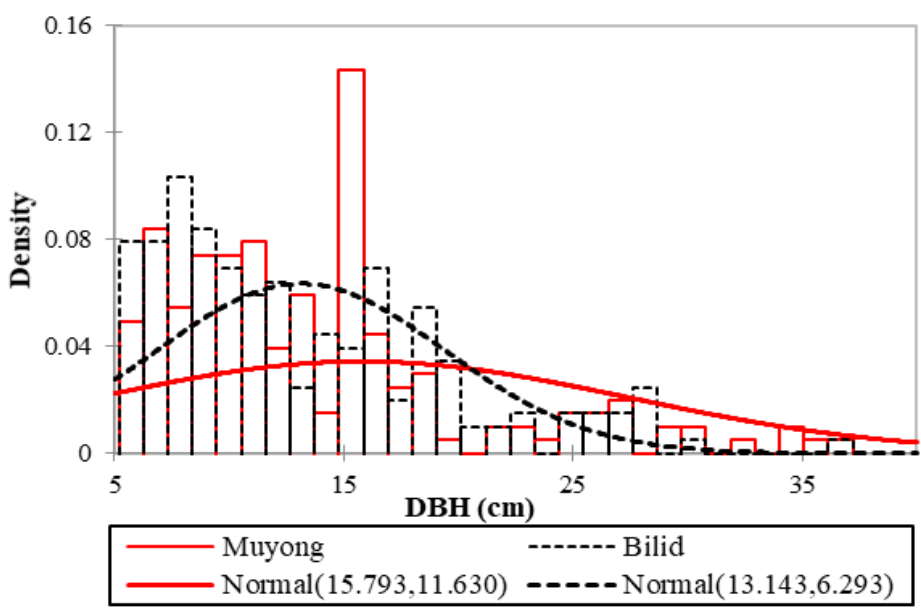

Figure 7. Histogram of tree density and DBH in muyong and bilid forests

In this study, Brown's (1997) allometric equation was used to determine the AGB based on DBH information. In tropical forests, the biomass of trees with $\mathrm{DBH}$ greater than $70 \mathrm{~cm}$ can account for $40 \%$ of the total forest biomass density, and these trees represent less than $5 \%$ of all trees (Brown and Lugo, 1992). Appendices A1 and A2 show the mean AGB (215 t/ha), BGB (38.9 t/ha) and total biomass (254.7 t/ha) recorded in the muyong forest, and the mean AGB (166.3 t/ha), BGB (33.5 t/ha) and total biomass (199.7 t/ha) recorded for bilid forest. The muyong forest had high average carbon stocks with $119.7 \pm 76$ tons of carbon per hectare (tC/ha) 
compared to the bilid which had $93.9 \pm 27.6$ tC/ha. Although the plots in the bilid showed high tree density compared to the muyong, the muyong showed higher total forest carbon stock values.

\subsubsection{Forest Floor Biomass}

Table 3 shows the amount of fresh and litter samples in the $1-\mathrm{m}^{2}$ sampling plots within the $10-\mathrm{m}^{2}$ plots. The bilid forest showed higher coverage of fresh and litter samples than the muyong forest. After the fresh samples were collected, they were oven-dried to determine the dry mass.

Table 3. Amounts of fresh and litter samples collected per square meter

\begin{tabular}{|l|r|r|r|}
\hline Forest types & Fresh (herbaceous) (g) & Litter (g) & Total Sample (g) \\
\hline Muyong & $419 \pm 188$ & $1,075 \pm 446$ & $1,494 \pm 481$ \\
\hline Bilid & $673 \pm 447$ & $1,776 \pm 412$ & $2,449 \pm 608$ \\
\hline
\end{tabular}

Table 4 shows the average dry mass and carbon content in the fresh and litter samples of the forest floor. The bilid showed higher average levels of dry mass in both fresh and litter samples than the muyong. The presence of high fresh and litter carbon in the bilid is due to the natural growth of herbaceous vegetation on the forest floor.

Table 4. Average dry mass and carbon content in the fresh and litter samples of the forest floor

\begin{tabular}{|l|l|l|l|l|l|l|}
\hline \multirow{3}{*}{ Forest types } & \multicolumn{5}{|l|}{ Average Dry Mass } & \multicolumn{2}{l|}{ Average Carbon } \\
\cline { 2 - 7 } & Fresh & Litter & Total & Fresh & Litter & Total \\
\cline { 2 - 7 } & $\mathbf{( t / h a )}$ & $\mathbf{( t / h a )}$ & $\mathbf{( t / h a )}$ & $\mathbf{( t C / h a )}$ & $\mathbf{( t C / h a )}$ & (tC/ha) \\
\hline Muyong & 2.99 & 7.93 & 10.92 & 1.41 & 3.73 & 5.13 \\
\hline Bilid & 4.86 & 13.15 & 18.01 & 2.28 & 6.18 & 8.46 \\
\hline
\end{tabular}

\subsubsection{Soil Carbon}

Soil carbon is the main contributor to forest carbon stocks next to AGB (Lal, 2005). Soil samples were collected from the 10 -cm topsoil layer to estimate SOC. The soil samples were oven-dried 
at $70^{\circ} \mathrm{C}$ for $48 \mathrm{~h}$ in the laboratory. They were then subjected to carbon content analysis under laboratory conditions. Table 5 shows the average soil organic carbon stock in muyong and bilid forests. The average SOC was 26.02 and $23.78 \mathrm{tC} /$ ha in the muyong and bilid forests, 353 respectively, to a soil depth of $10 \mathrm{~cm}$. The $0-10-\mathrm{cm}$ level of the soil is expected to be rich in 354 carbon owing to the presence of humus or organic matter accumulated from the decomposed litter (Ullah et al., 2012; Hobley et al., 2016). The soil carbon results revealed a higher SOC value in muyong than in bilid. This may be attributed to the bilid's greater exposure to sunlight and its greater susceptibility to soil erosion. Furthermore, the practices of weeding, regular thinning, and treatment can play a beneficial role in carbon sequestration in muyong. Finkral and Evas (2008) also reported that thinning treatments can re-establish ecological processes and help in ecosystem restoration and function.

Table 5. Average soil organic carbon stock

\begin{tabular}{|l|l|l|l|}
\hline $\begin{array}{l}\text { Forest } \\
\text { types }\end{array}$ & $\begin{array}{l}\text { Average Soil Bulk } \\
\text { Density }\end{array}$ & $\begin{array}{l}\text { Mean Soil Organic } \\
\text { Carbon (\%) }\end{array}$ & $\begin{array}{l}\text { Avg. Soil Organic } \\
\text { Carbon Stock (tC/ha) }\end{array}$ \\
\hline Muyong & $0.72+0.19$ & $3.88 \pm 0.09$ & $26.02 \pm 4.81$ \\
\hline Bilid & $0.73 \pm 0.03$ & $3.26 \pm 0.90$ & $23.78 \pm 0.98$ \\
\hline
\end{tabular}

\subsubsection{Total Carbon Stock}

Table 6 shows the total carbon stocks in the muyong and bilid. The results show that the carbon stock in the muyong was higher than that in the bilid. The average carbon stock in the muyong was estimated to be $150.86 \mathrm{tC} / \mathrm{ha}$ compared to the $126.14 \mathrm{tC} / \mathrm{ha}$ found in the bilid. The presence of large DBH trees in muyong forests can contribute to the majority of forest biomass, as has been confirmed by other studies (Brown \& Lugo, 1992; Brown et al., 1995; Culmsee, et al., 2010). Among the all-carbon pools, most of the carbon stock was in the AGB pool. Forest carbon stock information is important for planning, management, and carbon sequestration in the

371 Ifugao system. Information of this nature is essential to understanding carbon stock potential in 372 the forest system at a micro-level. Climate, soil type, topographic factors, and biotic factors are 373 the main determinants of forest biomass and its spatial distribution (Xu et al., 2015). Biomass 
374 accumulation in forests also varies according to microclimate and anthropogenic disturbances 375 (Brown and Lugo, 1990).

Table 6. Total carbon stocks based on field data

\begin{tabular}{|l|l|l|l|r|l|l|}
\hline $\begin{array}{l}\text { Forest } \\
\text { types }\end{array}$ & $\begin{array}{l}\text { AGB } \\
\text { (tC/ha) }\end{array}$ & $\begin{array}{l}\text { BGB } \\
\text { (tC/ha) }\end{array}$ & \multicolumn{2}{|l|}{ Forest Floor } & $\begin{array}{l}\text { Soil } \\
\text { carbon } \\
\mathbf{( 0 - 1 0 c m})\end{array}$ & $\begin{array}{l}\text { Total } \\
\text { Carbon } \\
\text { Stock }\end{array}$ \\
\hline & & & Fresh & Litter & (tC/ha) & (tC/ha) \\
\hline Muyong & 101.4 & 18.3 & 1.41 & 3.73 & 26.02 & 150.86 \\
\hline Bilid & 78.2 & 15.7 & 2.28 & 6.18 & 23.78 & 126.14 \\
\hline
\end{tabular}

\subsection{Carbon Stock Estimation using Indirect Measurement (remote sensing-based analysis)}

Geospatial data can be used to study forest biomass, which is fortunate, as conventional field-based methods are expensive and time-consuming. Moreover, conventional field-based methods are only applicable to small-scale analysis. Therefore, remote sensing-based methods can be applied to a larger area (Vashum et al., 2012). In this study, the maximum likelihood classification algorithm was used to classify AVNIR-2 data with the help of field data. Figure 8 shows the LULC map of the study area. The area was classified into seven classes: muyong, bilid, 385 rice terraces, built-up areas, grassy mountain area, open mountain, and water bodies. The classified image attempts to distinguish muyong (sea-green) forests from the bilid (green). Some misclassification with respect to bilid or muyong occurred owing to the presence of steep 389 (30.4\%) and muyong (29.5\%). 


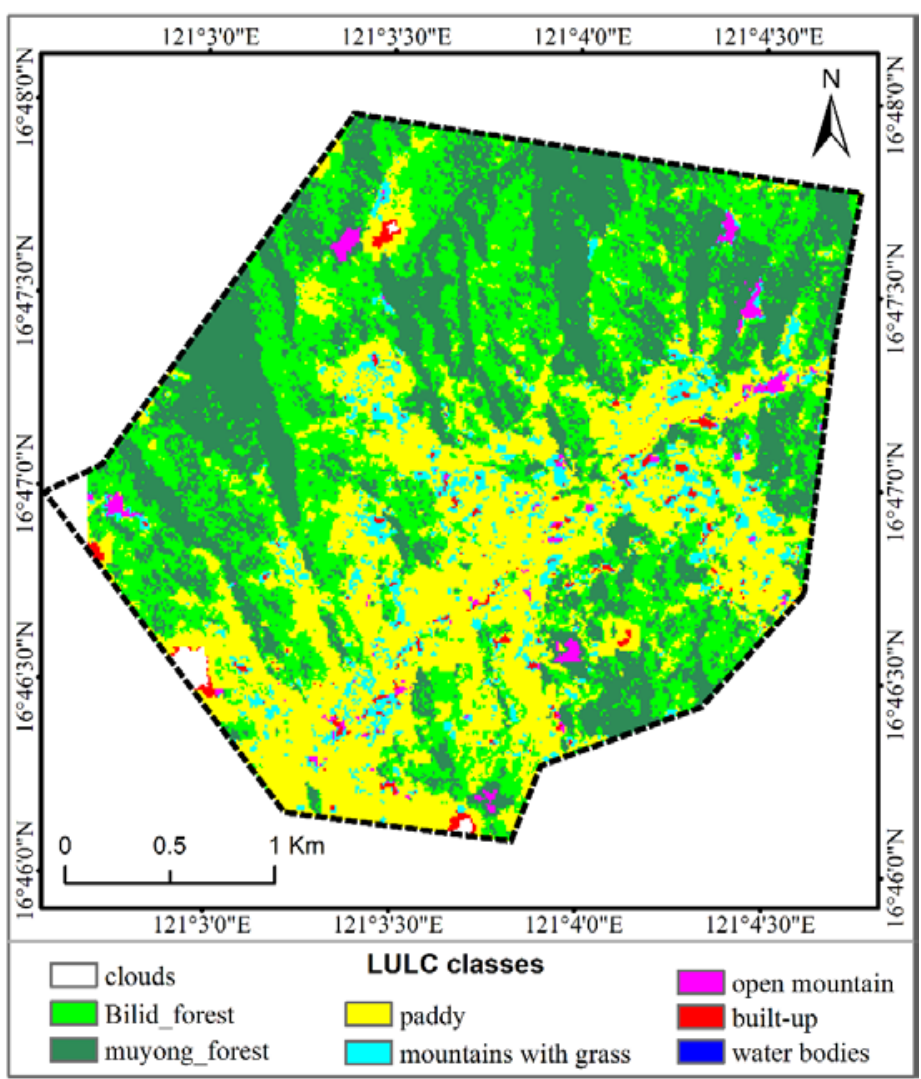

404

Figure 8. Land use/land cover map of the study area

405

AVNIR-2-based forest area information and average carbon stocks in bilid and muyong forests were used to estimate total carbon stocks. Table 7 shows the estimated average carbon 407 stocks in the muyong and bilid forests using field-based and remote sensing-based information. 408 The total carbon stocks were 401,061.3 and 369,804.6 tC in muyong and bilid forests, 409 respectively. This information will be useful for policy-makers in designing REDD+ policies for 410 the study area. Some uncertainties in the biomass estimation may potentially arise because soil 411 carbon up to soil depth of $10 \mathrm{~cm}$ is considered in this study.

412 Table 7. Total carbon stocks in muyong and bilid based on remote sensing and field data

\begin{tabular}{|c|c|c|c|}
\hline Forest Types & $\begin{array}{l}\text { Forest area (ha) } \\
(2010)\end{array}$ & $\begin{array}{l}\text { Average carbon stock } \\
\text { (tC/ha) }\end{array}$ & $\begin{array}{l}\text { Total carbon } \\
\text { stock (tC) }\end{array}$ \\
\hline Muyong & 2658.5 & 150.86 & 401061.3 \\
\hline Bilid & 2931.7 & 126.14 & 369804.6 \\
\hline
\end{tabular}


Avtar et al.'s (2013b) methodology was used to estimate AGB using PALSAR data. Figures 9a and 9b show the biomass map using PALSAR data and the slope map using SRTMDEM data from the study area. The slope map of the study area (Fig. 10b) clearly shows that most of the area had a slope greater than 20 degrees with the exception of the paddy fields. Therefore, the biomass estimation using PALSAR data may have low accuracy due to the topographic effects on SAR data. Attarchi and Gloaguen (2014) also noticed the effect of topography on PALSAR-based biomass estimation in a mountain forest in Iran and proposed the use of multi-satellite data to overcome topographic effects.

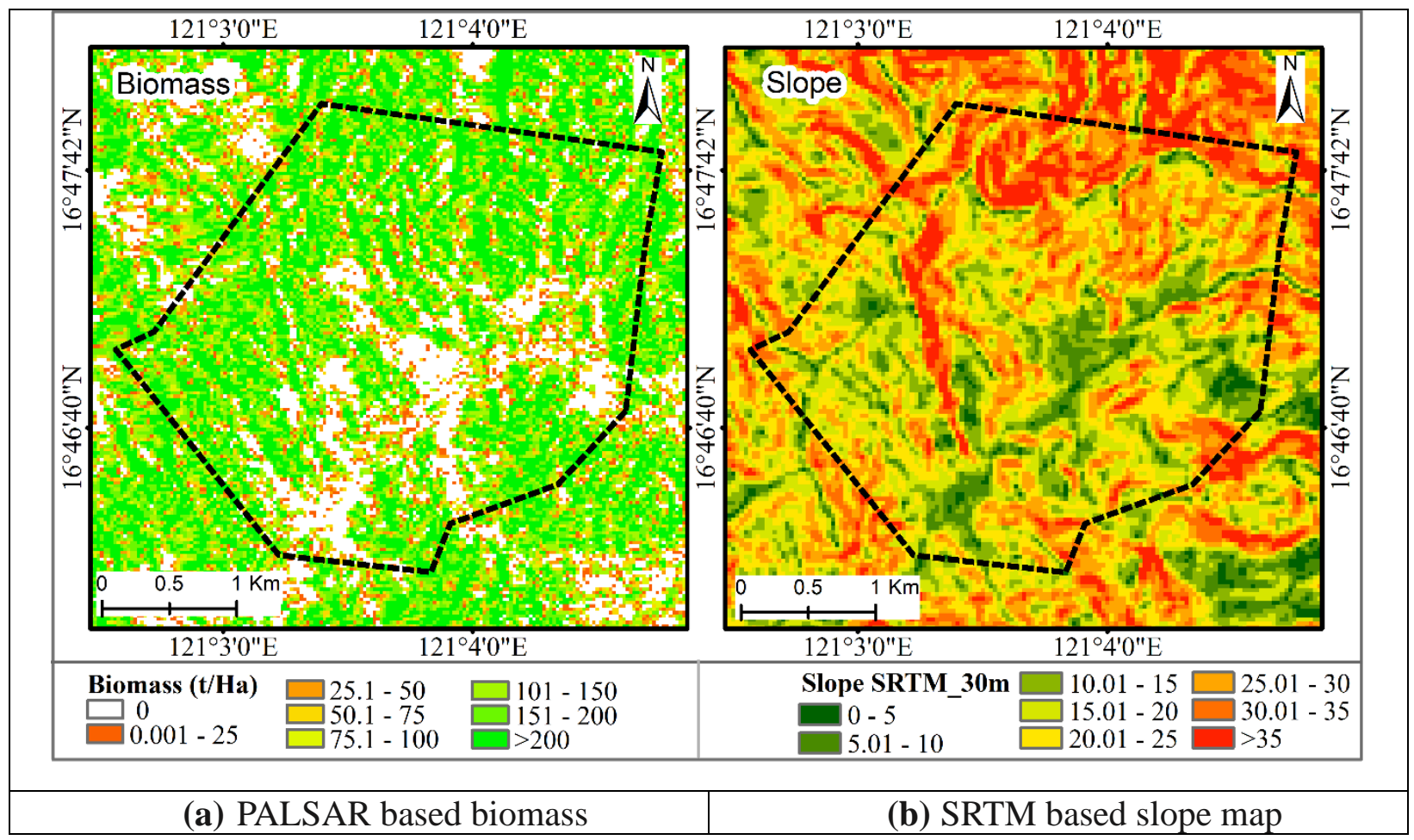

Figure (9a) PALSAR-based biomass of the study area (9b) SRTM-based slope map

Figure 10 shows a weak correlation $\left(\mathrm{R}^{2}=0.029\right)$ between PALSAR-estimated biomass and field-measured biomass. No significant relationship was observed with PALSAR-estimated biomass because most of the plots were on a steep slope and SAR data are not effective in steep areas owing to the topographic effects. Lone et al. (2017) also used PALSAR data to study the influence of slope and aspect in AGB estimation in India and found that topography influences the saturation of backscattering. The high slope areas have a high saturation limit of backscattering with 50-60 t/ha uncertainty. The key limitation to the PALSAR-based biomass estimation was the topographic effect of SAR data in the study area, which limits the 
applications of remote sensing techniques. To overcome the topographic limitations, LiDAR data can be useful for more precise biomass estimation in mountainous areas. Further studies on forests in other areas of Ifugao would be useful in addressing the lack of information available for remote sensing analysis. However, the potential for remote sensing opportunities in the area remains limited due to the cloud cover and topography.

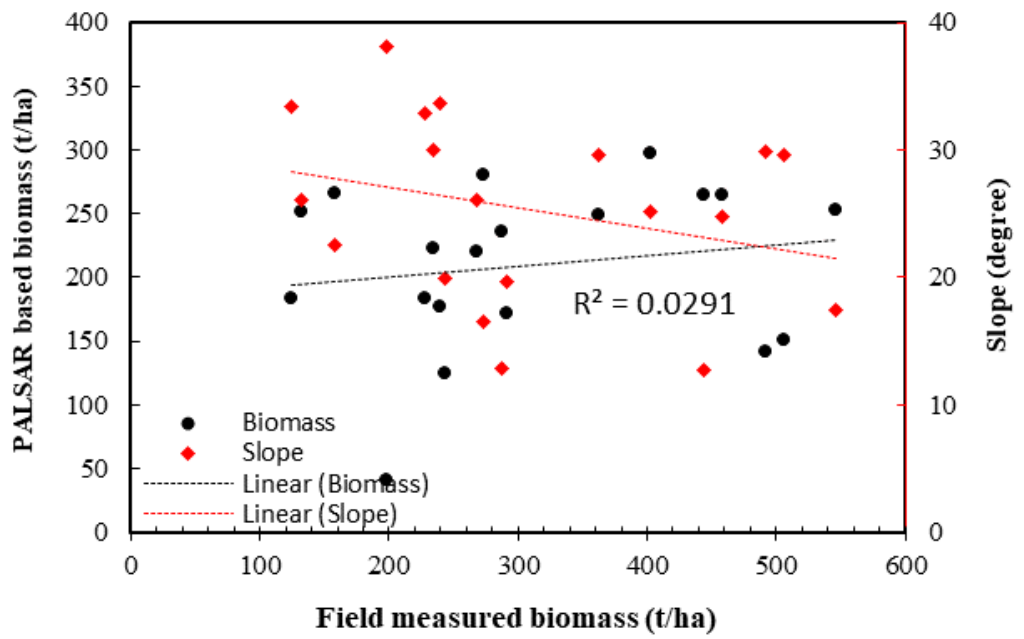

\section{Figure 10. Correlation between PALSAR-estimated biomass and field-measured biomass}

The estimation of total carbon stock is an important input for several current and future initiatives. The results can improve our understanding of how the muyong forest contributes potential carbon stock and the role of a landscape. The muyong forest showed higher total biomass than the bilid forest, and a greater difference in $\mathrm{DBH}$ was found in the muyong than in the bilid. Tree density is higher in the bilid forest than in the muyong, and this supports the hypothesis that the selective cutting and facilitated growth practices in the muyong are beneficial for carbon sequestration. Interestingly, the maintenance of muyong forests not only promotes carbon sequestration but also provides water for the rice fields during the dry season.

Implementation of the REDD+ mechanism can provide opportunities for the local people to conserve and manage the muyong system more sustainably in addition to reaping the financial benefits associated with carbon sequestration in the muyong system. Furthermore, the implementation of REDD+ can help protect the environment and biodiversity. It can conserve carbon stocks and provide a better adaptation mechanism to climate change in the Philippines, which is one of the climate change mitigation policies (Center et al., n.d.; Roe, 2012). 

people are struggling to sustain their livelihoods. Consequently, people have begun to leave the muyong area in search of employment elsewhere (Avtar et al., 2019). As part of the effort to reduce the outward migration of local people, REDD+ can make a positive impact with respect to long-term maintenance of the muyong forest. As a means of generating more income, REDD+ supports coffee tree growth in the muyong forest and taps into the organic food market rather than wood collection. Thus, REDD+ is still considered a promising means of creating incentives and other livelihood options to reduce deforestation and sustain the economic transformations of the Ifugao economy.

This preliminary study had several limitations, including the limited number of sampling plots and the relative spacing of sampling plots due to steep topography. Systematic sampling with a sufficient number of plots may be the optimal approach to accurately estimate total carbon stocks. The use of species-specific allometric equations may be more effective than generic allometric equations in reducing uncertainties (Kiyono et al., 2010; Samreth et al., 2012). We measured soil carbon only at a soil depth of $10 \mathrm{~cm}$, although earlier studies used soil carbon data from a soil depth of $1 \mathrm{~m}$. The number of sampling plots was also limited and should be increased to improve measurement accuracy. The use of permanent sampling plots (PSPs) may help to enhance the accuracy of carbon estimation (Samreth et al., 2012). Continuous monitoring is required to determine the rate of sequestration with the establishment of PSPs.

472 cloud cover and topographic conditions (i.e., slope). However, this could be improved through 473 the application of advanced topographic correction techniques (Umarhadi and Danoedoro, 2019) 474 as well as the use of high-resolution satellite data with object-based classification methods, such 475 as GEOBIA (Weih Jr. and Riggan Jr., 2010) and the use of advanced modeling methods to 476 estimate biomass, such as random forest (RF), stepwise regression (SR), and support vector 477 regression (SVR) (Liu et al., 2017). The use of multi-sensor remote sensing data can improve the 478 accuracy of image classification and biomass estimation. Improvement of biomass estimation is 479 essential for an effective measurement, reporting, and verification (MRV) system. The incentives 480 from REDD+ can help muyong forests with high carbon stock. The biomass products will also 
481 be useful for Sustainable Development Goals (SDG) Goal 15, which includes the improvement 482 of carbon management.

\section{5. Conclusions}

This study has demonstrated the effective use of direct and indirect methods to assess

forest carbon stocks. The results reveal that carbon stock differs among muyong and bilid forests of the Ifugao system, and most of the carbon stock is found in AGB. Field-based methods are useful for calculating average carbon stocks in muyong (150.86 tC/ha) and bilid (126.14 tC/ha) forests. Owing to the positive role of human interventions, muyong forests happen to sequester a larger amount of carbon (than the natural capacity). This makes the muyong an appropriate forest management system for the implementation of the REDD+ framework. These data can play an important role in filling the gaps in the existing national forest biomass estimation. It is essential that high-quality carbon stock data be generated to facilitate the monitoring of forest carbon and understanding resilience under the REDD+ mechanism. Remote sensing data have limited applications in the study area due to cloud cover and topographic effects. Accurate and reliable biomass estimation models are necessary for the non-destructive estimation of carbon stocks. Furthermore, carbon sequestration safeguards against deforestation and also helps to develop symbiotic linkages between agroforestry and biodiversity conservation. REDD+ mediation is expected to support the Ifugao economy by providing additional incentives and opportunities that will assist local communities in maintaining their traditional rice terraces system.

\section{Acknowledgment}

The authors extend their thanks to the Asia-Pacific Network for Global Change Research (ARCP2011-13NMY-Herath) for supporting the field research and Japan Aerospace Exploration Agency (JAXA) for providing satellite data (PER2A2N133). We are also thankful to people of Ifugao who helped during the fieldwork. We are also thankful to Dr. Dixon Tuzon Gevana and Dr. Diwa Johanna Paula for their supports and suggestions.

\section{References}


Anaya, J. A., Chuvieco, E., \& Palacios-Orueta, A. (2009). Aboveground biomass assessment in Colombia: A remote sensing approach. Forest Ecology and Management, 257(4), 12371246.

Andoh, J., \& Lee, Y. (2018). National REDD+ Strategy for Climate Change Mitigation: A Review and Comparison of Developing Countries. Sustainability, 10(12). https://doi.org/10.3390/su10124781

Attarchi, S., \& Gloaguen, R. (2014). Improving the estimation of above ground biomass using dual polarimetric PALSAR and ETM+ data in the Hyrcanian mountain forest (Iran). Remote Sensing, 6(5), 3693-3715.

Avtar, R., Sawada, H., Takeuchi, W., \& Singh, G. (2012). Characterization of forests and deforestation in Cambodia using ALOS/PALSAR observation. Geocarto International, 27(2), 119-137.

Avtar, R., Sawada, H., \& Kumar, P. (2013a). Role of remote sensing and community forestry to manage forests for the effective implementation of REDD+ mechanism: a case study on Cambodia. Environment, Development and Sustainability, 15(6), 1593-1603. https://doi.org/10.1007/s10668-013-9448-y

Avtar, R., Suzuki, R., Takeuchi, W., \& Sawada, H. (2013b). PALSAR 50 m Mosaic Data Based National Level Biomass Estimation in Cambodia for Implementation of REDD+ Mechanism. PLOS ONE, 8(10), e74807. https://doi.org/10.1371/journal.pone.0074807

Avtar, R., Takeuchi, W., \& Sawada, H. (2013c). Monitoring of biophysical parameters of cashew plants in Cambodia using ALOS/PALSAR data. Environmental monitoring and assessment, 185(2), 2023-2037. 
Avtar, R., Kumar, P., Oono, A., Saraswat, C., Dorji, S., \& Hlaing, Z. (2016). Potential application of remote sensing in monitoring ecosystem services of forests, mangroves and urban areas (Vol. 32). https://doi.org/10.1080/10106049.2016.1206974

Avtar, R., Tsusaka, K., \& Herath, S. (2019). REDD+ Implementation in Community-Based Muyong Forest Management in Ifugao, Philippines. Land, 8(11), 164. doi:10.3390/land8110164

Baccini, A., Friedl, M., Woodcock, C., \& Warbington, R. (2004). Forest biomass estimation over regional scales using multisource data. Geophysical research letters, 31(10).

Borah, J. R., Evans, K. L., \& Edwards, D. P. (2018). Quantifying carbon stocks in shifting cultivation landscapes under divergent management scenarios relevant to REDD. Ecological applications : a publication of the Ecological Society of America, 28(6), 1581-1593. https://doi.org/10.1002/eap.1764

Brown, Sandra. (1997). Estimating biomass and biomass change of tropical forests: a primer (Vol. 134). Food \& Agriculture Org.

Brown, SANDRA, \& Lugo, A. E. (1992). Aboveground biomass estimates for tropical moist forests of the Brazilian Amazon. Interciencia. Caracas, 17(1), 8-18.

Brown, I. F., Martinelli, L. A., Thomas, W. W., Moreira, M. Z., Ferreira, C. C., \& Victoria, R. A. (1995). Uncertainty in the biomass of Amazonian forests: An example from Rondonia, Brazil. Forest Ecology and Management, 75(1-3), 175-189.

Butic, M., \& Ngidlo, R. (2003). Muyong forest of Ifugao: assisted natural regeneration in traditional forest management. Advancing assisted natural regeneration (ANR) in Asia and the Pacific. Regional Office for Asia and the Pacific, Food and Agriculture Organization of the United Nations, Bangkok, Thailand, 23-27. 
553 Calderon, M., Dizon, J., Sajise, A., Andrada II, R., Bantayan, N., \& Salvador, M. (2009).

554

555

556

557

558

559

560

561

562

563

564

565

566

567

568

569

570

571

572

573

574

575

576

Towards the Development of a Sustainable Financing Mechanism for the Conservation of the Ifugao Rice Terraces in the Philippines.

Center, E. L. A., GOM, G. O. M., Asia, G. S., NGOs, K. I., Areas, D.-P., \& Bureau-DENR, W. (n.d.). The Philippine National REDD-plus Strategy.

Chave, J., Réjou-Méchain, M., Búrquez, A., Chidumayo, E., Colgan, M. S., Delitti, W. B., ... \& Henry, M. (2014). Improved allometric models to estimate the aboveground biomass of tropical trees. Global change biology, 20(10), 3177-3190.

Conklin, H. C. (1980). Ethnographic atlas of Ifugao; a study of environment, culture, and society in northern Luzon.

Culmsee, H., Leuschner, C., Moser, G., \& Pitopang, R. (2010). Forest aboveground biomass along an elevational transect in Sulawesi, Indonesia, and the role of Fagaceae in tropical montane rain forests. Journal of Biogeography, 37(5), 960-974.

Daniel, C. (2014). Government confirms Ifugao 'muyong' system. https://www.sunstar.com.ph/article/335314

Department of Environment and Natural Resources 2008. The Ifugao rice terraces Philippines project framework, GIAHS. http://www.fao.org/3/a-bp814e.pdf

Drake, J. B., Knox, R. G., Dubayah, R. O., Clark, D. B., Condit, R., Blair, J. B., \& Hofton, M. (2003). Above-ground biomass estimation in closed canopy neotropical forests using lidar remote sensing: Factors affecting the generality of relationships. Global ecology and biogeography, 12(2), 147-159.

Duncanson, L., Armston, J., Disney, M., Avitabile, V., Barbier, N., Calders, K., ... \& Falkowski, M. (2019). The importance of consistent global forest aboveground biomass product validation. Surveys in geophysics, 40(4), 979-999. 
577 Dugan, P., Durst, P. B., Ganz, D. J., \& McKenzie, P. J. (2003). Advancing assisted natural 578 regeneration (ANR) in Asia and the Pacific. RAP PUBLICATION, 19.

579 Durst, P. B., Waggener, T., Enters, T., \& Laycheng, T. (2001). Forests out of bounds: impacts 580 and effectiveness of logging bans in natural forests in Asia-Pacific. FAO.

581 582 583 584 585 586 587 588 589 590 591 592 593 594 595 596 597 598 599

Eggleston, S., Buendia, L., Miwa, K., Ngara, T., \& Tanabe, K. (2006). 2006 IPCC guidelines for national greenhouse gas inventories (Vol. 5). Institute for Global Environmental Strategies Hayama, Japan.

Englhart, S., Keuck, V., \& Siegert, F. (2011). Aboveground biomass retrieval in tropical forests-The potential of combined X-and L-band SAR data use. Remote sensing of environment, 115(5), 1260-1271.

FAO. (2015). In Global Forest Resources Assessment 2015 Country Report Philippines. Forestry Department Food and Agriculture Organization of the United Nations, 164, 5.

Finkral, A. J., \& Evans, A. M. (2008). The effects of a thinning treatment on carbon stocks in a northern Arizona ponderosa pine forest. Forest Ecology and Management, 255(7), 27432750 .

Hobley, E. U., \& Wilson, B. (2016). The depth distribution of organic carbon in the soils of eastern Australia. Ecosphere, 7(1), e01214.

Houghton, R. A. (2003). Why are estimates of the terrestrial carbon balance so different? Global Change Biology, 9(4), 500-509. https://doi.org/10.1046/j.1365-2486.2003.00620.x

Herath, S., Tsusaka, K., \& Diwa, J. (2015). Assessment on the feasibility of REDD+ in Nagacadan Rice Terraces of Ifugao and its muyong forest. United Nations University Institute for the Advanced Study of Sustainability: Tokyo, Japan. 
600

601

602

603

604

605

606

607

608

609

610

611

612

613

614

615

616

617

618

619

620

621

622

Jang, J. W., \& Salcedo, S. (2013). The socio-political structure that regulates the Ifugao Forest Maintenance (Vol. 58, pp. 85-94). Presented at the 2013 4th international conference on biology, environment and chemistry, IPCBEE.

Kiyono, Y., Furuya, N., Sum, T., Umemiya, C., Itoh, E., Araki, M., \& Matsumoto, M. (2010). Carbon stock estimation by forest measurement contributing to sustainable forest management in Cambodia. Japan Agricultural Research Quarterly: JARQ, 44(1), 81-92.

Lal, R. (2005). Forest soils and carbon sequestration. Forest Soils Research: Theory, Reality and its Role in TechnologY, 220(1), 242-258. https://doi.org/10.1016/j.foreco.2005.08.015

Lasco, R. D., Mallari, N. A. D., Pulhin, F. B., Florece, A. M., Rico, E. L. B., Baliton, R. S., \& Urquiola, J. P. (2013). Lessons from early REDD. International Journal of Forestry Research, 2013.

Lindsell, J. A., \& Klop, E. (2013). Spatial and temporal variation of carbon stocks in a lowland tropical forest in West Africa. Forest Ecology and Management, 289, 10-17.

Liu, K., Wang, J., Zeng, W., \& Song, J. (2017). Comparison and evaluation of three methods for estimating forest above ground biomass using TM and GLAS data. Remote Sensing, 9(4), 341.

Lillesand, T., Kiefer, R. W., \& Chipman, J. (2015). Remote sensing and image interpretation. John Wiley \& Sons.

Lone, J., Sivasankar, T., Sarma, K. K., Qadir, A., \& L N Raju, P. (2017). Influence of Slope Aspect on above Ground Biomass Estimation using ALOS-2 Data (Vol. 6). https://doi.org/10.21275/ART20174506

Matsushima, N., \& Tojo, Y. (2010). Satoyama Initiative: Use and Management of “Muyong” in Ifugao Province, Northern Luzon Island in the Philippines. 
Ma, L., Shen, C. Y., Fu, S. L., Lian, J. Y., \& Ye, W. H. (2018). TEMPORAL AND SPATIAL PATTERNS IN ABOVEGROUND BIOMASS WITHIN DIFFERENT HABITATS IN A SUB-TROPICAL FOREST. Journal of Tropical Forest Science, 30(2), 143-153.

McGroddy, M.E., Daufresne, T. and Hedin, L.O. (2004). Scaling of C:N:P stoichiometry in forests worldwide: Implications of terrestrial Redfield-type ratios. Ecology 85: 23902401.

Minh, H. V. T., Avtar, R., Mohan, G., Misra, P., \& Kurasaki, M. (2019). Monitoring and Mapping of Rice Cropping Pattern in Flooding Area in the Vietnamese Mekong Delta Using Sentinel-1A Data: A Case of An Giang Province. ISPRS International Journal of Geo-Information, 8(5). https://doi.org/10.3390/ijgi8050211

Marín-Spiotta, E., \& Sharma, S. (2013). Carbon storage in successional and plantation forest soils: a tropical analysis. Global Ecology and Biogeography, 22(1), 105-117.

Nelson, R., Krabill, W., \& Tonelli, J. (1988). Estimating forest biomass and volume using airborne laser data. Remote Sensing of Environment, 24(2), 247-267. https://doi.org/10.1016/0034-4257(88)90028-4

Nelson DW, Sommers LE (1996) Total carbon, organic matter. In: Sparks DL et al (eds) Method of soil analysis. Part 3. Chemical methods. Soil Science Society of America, Madison, pp 961-1010

O’Connor, R. A. (1995). Agricultural change and ethnic succession in Southeast Asian states: a case for regional anthropology. The Journal of Asian Studies, 54(4), 968-996.

Pearson, T., Walker, S., \& Brown, S. (2013). Sourcebook for land use, land-use change and forestry projects.

Ravindranath, N., \& Ostwald, M. (2008). Methods for estimating above-ground biomass. Carbon inventory methods handbook for greenhouse gas inventory, carbon mitigation and roundwood production projects, 113-147. 
Racelis, E. L., Carandang, W. M., Lasco, R. D., Racelis, D. A., Castillo, A. S., \& Pulhin, J. M. (2008). Assessing the carbon budgets of large leaf mahogany (Swietenia macrophylla King) and Dipterocarp plantations in the Mt. Makiling Forest Reserve, Philippines. Journal of Environmental Science and Management, 11(1).

Samreth, V., Chheng, K., Monda, Y., Kiyono, Y., Toriyama, J., Saito, S., ... \& Ito, E. (2012). Tree biomass carbon stock estimation using permanent sampling plot data in different types of seasonal forests in Cambodia. Japan Agricultural Research Quarterly: JARQ, 46(2), 187-192.

Soriano, M. A., \& Herath, S. (2019). Climate change and traditional upland paddy farming: a Philippine case study. Paddy and Water Environment, 1-14.

Tadono, T., Shimada, M., Murakami, H., \& Takaku, J. (2009). Calibration of PRISM and AVNIR-2 onboard ALOS "Daichi”. IEEE Transactions on Geoscience and Remote Sensing, 47(12), 4042-4050.

Takahashi, K., Ikeyama, Y., \& Okuhara, I. (2018). Stand dynamics and competition in a mixed forest at the northern distribution limit of evergreen hardwood species. Ecology and evolution, 8(22), 11199-11212.

Timothy, D. J., \& Nyaupane, G. P. (2009). Cultural heritage and tourism in the developing world: A regional perspective. Routledge.

Toorn, S. I. aan den. (2013, August 31). Conserving the Ifugao Rice Terraces World Heritage Site: Financing cultural landscapes in a less-developed country through an ecosystem services framework (Bachelor). Faculty of Archaeology, The Netherlands.

UNESCO. (2019, April 1). Rice Terraces of the Philippine Cordilleras. http://whc.unesco.org/en/list/722

UN-REDD, P. (2016). Global \& Regional Support. https://www.un-redd.org/. Accessed 1 April 2019 
673 Umarhadi, D. A., \& Danoedoro, P. (2019, November). Correcting topographic effect on Landsat-

674

675

676

677

678

679

680

681

682

683

684

685

686

687

688

689

690

691

692

693

694

695

696

697

8 images: an evaluation of using different DEMs in Indonesia. In Sixth Geoinformation Science Symposium (Vol. 11311, p. 113110L). International Society for Optics and Photonics.

Ullah, M. R., \& Al-Amin, M. (2012). Above-and below-ground carbon stock estimation in a natural forest of Bangladesh. Journal of forest science, 58(8), 372-379.

Vashum, K. T., \& Jayakumar, S. (2012). Methods to estimate above-ground biomass and carbon stock in natural forests-A review. J. Ecosyst. Ecogr, 2(4), 1-7.

Walkley A, Black IA (1934) An examination of Degtjareff method for detemination soil organic matter and a proposed modification of the chromic acid titration method. Soil Sci 37:29_ 37

Weih, R. C., \& Riggan, N. D. (2010). Object-based classification vs. pixel-based classification: comparative importance of multi-resolution imagery. The International Archives of the Photogrammetry, Remote Sensing and Spatial Information Sciences, 38(4), C7.

World bank. (2010). A Strategic Approach to Climate Change in the Philippines. Sustainable Development Department East Asia \& Pacific Region.

Wondo Genet, E. (2013). Training manual on: forest carbon pools and carbon stock assessment in the context of SFM REDD+. https://pdfs.semanticscholar.org/4559/ca2a2516838d03103cec1a8ea07ddac51e8b.pdf access on 9 July 2015

Xu, Y., Franklin, S. B., Wang, Q., Shi, Z., Luo, Y., Lu, Z., ... \& Jiang, M. (2015). Topographic and biotic factors determine forest biomass spatial distribution in a subtropical mountain moist forest. Forest ecology and management, 357, 95-103. 
698

699

\begin{tabular}{l|l|l}
\hline Muyong & AGB & BGB
\end{tabular}

\begin{tabular}{|l|l|l|}
\hline Muyong & AGB & BGB \\
\hline
\end{tabular}

\begin{tabular}{|c|c|c|c|c|c|c|c|c|}
\hline & $\mathrm{kg}$ & tor & $\mathrm{kg}$ & n & $k \sigma$ & n & $\gamma$ & ab \\
\hline M01 & 666.22 & 70.1 & 133.30 & 14.0 & 799.52 & 84.1 & 375.8 & 39.5 \\
\hline
\end{tabular}

\begin{tabular}{|l|r|r|r|r|r|r|r|r|}
\hline M02 & 2345.49 & 246.6 & 417.87 & 43.9 & 2763.36 & 290.6 & 1298.8 & 136.6 \\
\hline
\end{tabular}

\begin{tabular}{|l|r|r|r|r|r|r|r|r|}
\hline M03 & 3167.92 & 333.1 & 535.70 & 56.3 & 3703.62 & 389.4 & 1740.7 & 183.0 \\
\hline M04 & 1066.22 & 112.1 & 209.00 & 22.0 & 1275.21 & 134.1 & 599.3 & 63.0 \\
\hline M05 & 2465.64 & 259.3 & 515.15 & 54.2 & 2980.79 & 313.4 & 1401.0 & 147.3 \\
\hline
\end{tabular}

\begin{tabular}{|l|r|r|r|r|r|r|r|r|}
\hline M05 & 2465.64 & 259.3 & 515.15 & 54.2 & 2980.79 & 313.4 & 1401.0 & 147.3 \\
\hline M06 & 1008.68 & 106.1 & 191.53 & 20.1 & 1200.21 & 126.2 & 564.1 & 59.3 \\
\hline
\end{tabular}

\begin{tabular}{|l|r|r|r|r|r|r|r|r|}
\hline M07 & 1500.47 & 157.8 & 291.27 & 30.6 & 1791.74 & 188.4 & 842.1 & 88.5 \\
\hline M08 & 1965.55 & 206.7 & 375.16 & 39.4 & 2340.72 & 246.1 & 1100.1 & 115.7 \\
\hline
\end{tabular}

\begin{tabular}{|l|r|r|r|r|r|r|r|r|}
\hline M08 & 1965.55 & 206.7 & 375.16 & 39.4 & 2340.72 & 246.1 & 1100.1 & 115.7 \\
\hline M09 & 5421.45 & 570.0 & 834.79 & 87.8 & 6256.24 & 657.8 & 2940.4 & 309.2 \\
\hline
\end{tabular}

\begin{tabular}{|l|r|r|r|r|r|r|r|r|}
\hline M10 & 1248.71 & 131.3 & 240.64 & 25.3 & 1489.35 & 156.6 & 700.0 & 73.6 \\
\hline
\end{tabular}

\begin{tabular}{|l|r|r|r|r|r|r|r|r|}
\hline M11 & 1723.20 & 181.2 & 322.56 & 33.9 & 2045.76 & 215.1 & 961.5 & 101.1 \\
\hline Average & $\mathbf{2 0 5 2 . 7}$ & $\mathbf{2 1 5 . 8}$ & $\mathbf{3 6 9 . 7}$ & $\mathbf{3 8 . 9}$ & $\mathbf{2 4 2 2 . 4 1}$ & $\mathbf{2 5 4 . 7}$ & $\mathbf{1 1 3 8 . 5}$ & $\mathbf{1 1 9 . 7}$ \\
\hline $\begin{array}{l}\text { Std. } \\
\text { Dev }\end{array}$ & $\mathbf{1 3 3 8 . 0}$ & $\mathbf{1 4 0 . 7}$ & $\mathbf{2 0 1 . 5}$ & $\mathbf{2 1 . 2}$ & $\mathbf{1 5 3 7 . 1}$ & $\mathbf{1 6 1 . 6}$ & $\mathbf{7 2 2 . 5}$ & $\mathbf{7 6 . 0}$ \\
\hline
\end{tabular}

700

701

Table A2. Bilid Forest Carbon Stock

\begin{tabular}{|l|r|r|r|r|r|r|r|r|}
\hline Bilid & \multicolumn{2}{|c|}{ AGB } & \multicolumn{2}{c|}{ BGB } & \multicolumn{2}{c|}{ AGB+BGB } & \multicolumn{2}{c|}{ C Stock } \\
\hline & $\mathrm{kg}$ & tons/ha & $\mathrm{kg}$ & tons/ha & $\mathrm{kg}$ & tons/ha & $\mathrm{kg}$ & tons/ha \\
\hline B01 & 1383.0 & 145.4 & 264.6 & 27.8 & 1647.6 & 173.2 & 774.4 & 81.4 \\
\hline B02 & 1243.6 & 130.8 & 252.9 & 26.6 & 1496.5 & 157.3 & 703.4 & 73.9 \\
\hline B03 & 1324.9 & 139.3 & 273.2 & 28.7 & 1598.1 & 168.0 & 751.1 & 79.0 \\
\hline B04 & 915.9 & 96.3 & 196.6 & 20.7 & 1112.5 & 117.0 & 522.9 & 55.0 \\
\hline B05 & 1542.0 & 162.1 & 303.1 & 31.9 & 1845.1 & 194.0 & 867.2 & 91.2 \\
\hline B06 & 2389.5 & 251.2 & 464.9 & 48.9 & 2854.4 & 300.1 & 1341.6 & 141.0 \\
\hline
\end{tabular}




\begin{tabular}{|l|r|r|r|r|r|r|r|r|}
\hline B07 & 1589.8 & 167.2 & 346.3 & 36.4 & 1936.2 & 203.6 & 910.0 & 95.7 \\
\hline B08 & 2262.8 & 237.9 & 443.6 & 46.6 & 2706.3 & 284.6 & 1272.0 & 133.8 \\
\hline Average & $\mathbf{1 5 8 1 . 4}$ & $\mathbf{1 6 6 . 3}$ & $\mathbf{3 1 8 . 2}$ & $\mathbf{3 3 . 5}$ & $\mathbf{1 8 9 9 . 6}$ & $\mathbf{1 9 9 . 7}$ & $\mathbf{8 9 2 . 8}$ & $\mathbf{9 3 . 9}$ \\
\hline $\begin{array}{l}\text { Std. } \\
\text { Dev }\end{array}$ & $\mathbf{4 7 1 . 8}$ & $\mathbf{4 9 . 6}$ & $\mathbf{8 8 . 2}$ & $\mathbf{9 . 3}$ & $\mathbf{5 5 9 . 4}$ & $\mathbf{5 8 . 8}$ & $\mathbf{2 6 2 . 9}$ & $\mathbf{2 7 . 6}$ \\
\hline
\end{tabular}

702 